\title{
A FUNÇÃO SOCIAL DA PROPRIEDADE RURAL
}

\author{
THE SOCIAL FUNCTION OF RURAL PROPERTY
}

\section{Ricardo Maravalhas de Carvalho BARROS* Lourival José de OLIVEIRA**}

\begin{abstract}
* Advogado com escritório constituído na cidade de Marília, militante nos Estados do Mato Grosso do Sul, Minas Gerais, Paraná e São Paulo. Especialista pela Universidade de Londrina/PR. Mestrando em Direito pela Universidade de Marília/Sp.

** Doutor em Direito das Relações Sociais (PUC-SP). Docente do Programa de Mestrado da Unimar; Docente da Universidade Estadual de Londrina; Docente da Universidade Norte do Paraná; Docente da Faculdade Paranaense.
\end{abstract}

\section{Resumo}

Com o presente artigo buscou-se trazer os aspectos jurídicos da função social da propriedade rural, seus requisitos constitucionais e a míope discussão prática sobre o tema. Abordou-se, inicialmente, o pensamento clássico ocidental, desde a visão da propriedade como direito absoluto, até sua evolução atingindo o estágio atual. Em seguida o tema função social foi localizado no plano constitucional, definindo seus requisitos válidos. Concluiu-se com o presente artigo que há hoje, em nossa sociedade, equivocada discussão prática quanto à exigência e ao cumprimento da função social, especialmente pelas partes envolvidas, quer sejam os proprietários rurais, os trabalhadores rurais, o INCRA ou o judiciário. Desta forma, em virtude do desvio de discussão, o artigo 186 da Constituição Federal torna-se letra morta, deixando de ser aplicado e, por consequência, há o atravancamento da reforma agrária no País por absoluta falta de terra desapropriável.

Palavra-chave: função social; propriedade rural.

\section{Abstract}

The present article has tried to bring the judicial aspects of the social function in rural property, its constitutional requirements and the myopic practical discussion about this subject. In the beginning, we've focused the classical westerner thoughts, since property was believed to be an absolute right, to its evolution up to now. After that, the social function subject was located in the constitutional plan defining its valid requirements. It was concluded in the present article that there is today, in our society, wrong practical discussion in the accomplishment of the social function, especially by the involved parts, such as the property owners, the workers, INCRA (National Institute for Colonization and Agrarian Reform) and the judicial system. So, because of the discussion divert, the 186 article of the Federal Constitution has become a dead word, not being applied and 
consequently, there is the obstruction of the agrarian reform in the country for an absolute lack of condemning land.

Key words: social function; rural property.

A discussão em torno da função social da propriedade rural há tempos tem obtido grande importância, principalmente pelas partes envolvidas, sendo elas os movimentos sociais, os proprietários de terras rurais, o INCRA e o Judiciário entre outros.

Ocorre que a discussão, como está posta, acaba por encobrir as possibilidades práticas deixadas pelo poder constituinte de 1988. As partes interessadas apenas e tão somente discutem os aspectos econômicos da função social da propriedade rural, dando ênfase aos índices de produtividade.

Não estão em discussão atualmente os outros aspectos intrínsecos à função social descritos no artigo 186 da Constituição Federal, tais como o respeito à legislação ambiental, às relações de trabalho, ao desenvolvimento social regional e à dignidade da pessoa humana.

Pretende-se, com esse trabalho, demonstrar que há, por força legal, inúmeras possibilidades de desapropriação de propriedade rurais para fim da reforma agrária e não somente aquelas lastreadas nos índices econômicos de produtividade e que, isso se fosse implementado, traria benefícios sociais a todo o país.

\section{Conceito de propriedade da terra através da evolução do pensamento ocidental}

Para compreender-se a razão da existência da propriedade privada na sociedade, a razão de sua proteção, bem como a evolução dessa proteção, em primeiro lugar se faz necessário buscar, nos clássicos modernos, o pensamento jurídico acerca da propriedade privada e a evolução desse pensamento até chegar ao conceito hoje utilizado em quase todos os sistemas jurídicos vigentes.

Até o fim do século XIX, o Estado era visto e concebido de forma que o homem fosse o centro do direito absoluto e individual; entendia-se que para a validade do direito e da regulação da vida em sociedade, a propriedade e sua relação com o homem desempenhavam papel central de interesse exclusivamente privado e individual.

Nessa época vários pensadores despontavam no mundo ocidental, podendo-se citar, inicialmente, Thomas Hobbes (1588-1679), para quem os indivíduos têm um desejo natural de se tornarem proprietários, porém a propriedade deve ser fonte de um pacto válido. A teoria hobbesiana é de singular 
importância para o tema ora discutido no sentido de que seu pensamento trouxe a necessidade intersubjetiva do homem em ser proprietário.

Segundo Hobbes essa condição acaba por criar entre os homens um estado permanente de guerra, no qual se acaba confundindo direito e lei, necessitando então de regulamentação por meio de contratos e da propriedade.

Dado que a condição do homem - conforme foi declarado no capítulo anterior - é uma condição de guerra de todos contra todos, sendo neste caso cada um governado por sua própria razão, não havendo nada de que possa lançar mão, que não possa lhe servir de ajuda para a preservação de sua vida contra seus inimigos, segue-se que em tal condição todo homem tem o direito a todas as coisas, incluindo os corpos dos outros. Ora, enquanto perdurar esse direito de cada homem a todas as coisas, não poderá haver para nenhum homem - por mais forte e sábio que seja - a segurança de viver o tempo que geralmente a natureza permitem aos homens viver. ${ }^{1}$

Nota-se que, na teoria aqui levantada, a propriedade passa a ser meio de pacificação social, regra geral da razão humana segundo o próprio pensador clássico aqui discutido: "É preceito ou regra geral da razão, que todo homem deve se esforçar pela paz [...]". ${ }^{2}$

Hobbes entendia que, ao sair do estado da natureza, para que se viabilizasse a paz social, a propriedade seria necessária e indispensável.

Em síntese, segundo a teoria em questão, a propriedade é valida se for fonte de um pacto válido entre as partes, sendo a mesma propriedade um dos princípios basilares para a constituição do Estado. ${ }^{3}$

Não menos brilhante que Hobbes, Locke (1632-1704) ensinou inicialmente que para apropriedade ter algum valor seria necessário à aplicação do trabalho humano sobre a terra, pois a terra sem trabalho humano não possuía qualquer valor, pertencendo a todos os que estão no estado de natureza.

Embora a terra e todas as criaturas inferiores sejam comuns a todos os homens, ainda assim todo o homem tem uma 'propriedade' em sua própria 'pessoa'. Ninguém tem direito algum sobre ela a não ser ele mesmo. O 'trabalho' de seu corpo e a 'obra' de suas mãos podemos dizer, são propriamente dele. Então, tudo o que ele retire do Estado que a natureza proporcionou, misturando-o ao seu trabalho e juntando-lhe algo que é seu, converte-se por isso em propriedade sua. ${ }^{4}$

1 HOBBES, Thomas. Leviatã. Trad. Alex Marins. São Paulo: Martin Claret, 2002, p. 101.

2 Idem. Ibidem.

3 Idem. Ibidem.

4 HOBBES, Thomas. Os grandes filósofos do direito. São Paulo: Martins Fontes, 2002. p. 138.

19 | ARGUMENTUM - Revista de Direito n. 9, p. 17-38, 2008 - UNIMAR 
A terra somente torna-se propriedade privada por meio do trabalho que o homem empreende sobre ela para obtê-la e para obter seus frutos.

Mais adiante, finalizando o capítulo acerca da propriedade, indicando a evolução do homem, do Estado e da própria propriedade e de certa forma, da própria sociedade ocidental, Locke admite a posse da terra superior à própria força do trabalho humano, com direito ao comércio da produção excedente e o dever de regulamentação por uma constituição positiva, ante a importância da propriedade para a sociedade.

Como, porém, o ouro e a prata, sendo pouco úteis para a vida do homem em comparação com o alimento, o vestuário e o transporte, só derivam seu valor de consentimento dos homens - do qual o trabalho ainda constitui, em grande parte, a medida - é claro que o consentimento dos homens concordou com a posse desproporcional e desigual da terra - quero dizer, fora dos limites da sociedade e do pacto; pois nos governos as leis a regulam. E, por consenso encontram uma maneira - e com ela concordam - de que o homem pudesse possuir, de maneira legítima e sem dano, mais do que podia usar, recebendo pelo excedente ouro e prata, que continuam por longo tempo na posse de um homem sem se deteriorar, e concordaram esses metais deveriam ter um valor. ${ }^{5}$

Assim como Hobbes, Locke também reconhece, em sua obra, a importância da propriedade para a manutenção da paz social, sendo vital para a sobrevivência pacífica do homem na terra.

Por seu turno, Rousseau (1712-1778) também influenciou o mundo moderno; para ele, a propriedade era essencial para a pacificação social, sendo produto de um pacto social válido e existente.

Todo o homem tem naturalmente direito a tudo o que lhe é necessário; mas o ato positivo que o torna proprietário e algum bem o exclui de todo o resto; estando feita a sua parte, a ela se deve limitar, e não tem mais direito à comunidade. Eis porque o direito de primeiro ocupante, assaz débil no estado de natureza, é para todo o homem civil, respeitável $[\ldots] .^{6}$

Mesmo que de forma tímida, quase sutil, é possível perceber na obra de Rousseau um pequeno viés social que este dá à propriedade. Trata-se de uma

5 Idem, ibidem, p. 141

6 ROUSSEAU, Jean-Jacques. Do contrato social. São Paulo: Martin Claret, 2003, p. 35. 
pequena centelha em que o pensador reconhece que a propriedade é subordinada não só pelo interesse individual, mas também pelo interesse que a sociedade tem sobre todos os interesses individuais.

Qualquer que seja a forma de aquisição, o direito que cada indivíduo tem sobre seu patrimônio está sempre subordinado ao direito que a comunidade tem sobre todos; sem isso não haveria estabilidade no vínculo social, nem força verdadeira no exercício da soberania. ${ }^{7}$

Rousseau não exclui o que já afirmavam outros autores, de que os homens têm direito a condições dignas de sobrevivência, este para o autor é um direito natural, todavia, é uma ação positiva, dentro de um interesse comunitário sobreposto ao individual, que o torna proprietário.

Por meio das idéias de Rousseau a propriedade da terra passou a ser regulamentada juridicamente, devendo ser preservada por lei.

A filosofia individualista tornou-se perfeitamente conveniente para os capitalistas produtores que começavam a entrar no ramo do comércio. A partir disso, as relações entre os homens passaram a ser vistas cada vez mais sob uma perspectiva de conflitos de interesses individuais e não de integração social com base em valores e normas.

Com a evolução natural do direito, que possui, como dever máximo e desafiador, o acompanhamento da evolução social sob pena de se tornar ineficaz ao seu fim, surgiu corrente contra a absoluta força da propriedade e do homem individual, aclamando-se, primeiro, a destituição da propriedade privada em decorrência da propriedade estatal.

O paradigma do Estado Social foi sendo lentamente construído a partir da década de 30 do século XIX, por meio de movimentos em defesa da classe e dos interesses operários.

Em meados do século XIX, Marx e Engels por meio da edição do Manifesto do Partido Comunista ${ }^{8}$ e do festejado Manuscritos econômicos e filosóficos, negaram totalmente o conceito de propriedade privada, principalmente a agrária, e de todos os outros bens de produção. Marx, aliás, apostava no comunismo que permitiria "a eliminação positiva da propriedade privada como auto-alienação humana e, desta forma, a real apropriação da essência humana pelo e para o homem".

\footnotetext{
7 Idem, ibidem, p. 35.

8 MARX, Karl, ENGELS, Friedrich. Manifesto do Partido Comunista. São Paulo: Martin Claret, 2002.

9 Idem, ibidem, p. 138.
} 
Segundo Ana Frazão de Azevedo Lopes ${ }^{10}$, o comunismo surgiu como uma forma de suplantar a auto-alienação e assegurar a plenitude do homem. Para o comunismo, a sociedade burguesa ancorada e legitimada pelo estado liberal, longe de ter abolido diferenças, estabeleceu novas classes, novas condições de opressão, novas formas de lutar no lugar das antigas.

Assim, num passo adiante em relação às idéias marxistas, como um peso mediano fazendo força de contraponto às idéias socialistas e liberais, surge a idéia de que, para superar a crise social existente, estabelecida pelo Estado Liberal, seria necessário uma reforma social.

Tal passo foi dado no século XX, na esteira do pensamento de Augusto Comte $^{11}$, pai do positivismo sociológico, segundo o qual a ciência deveria se basear exclusivamente nos fatos positivos observados e identificados pelas leis causais. Comte propôs, segundo Ana Frazão de Azevedo Lopes ${ }^{12}$, resolver a crise do mundo moderno por meio do estudo das leis da sociedade, a partir das quais se poderia estabelecer um sistema de idéias científicas que presidiria a reorganização social.

Seguindo na esteira de Comte, importante lembrar o pensamento de Leon Duguit $^{13}$, para quem a propriedade nada mais era do que produto momentâneo da evolução social, sendo o direito do proprietário limitado pela missão social que lhe incumbe. Aliás, segundo Gustavo Tepedino e Anderson Schreiber ${ }^{14}$, a Duguit é devida a difusão do termo "função social da propriedade".

Com a concepção da propriedade direito natural, fica-se ao mesmo tempo na impossibilidade de limitar o exercício do direito de propriedade. A propriedade individual deve ser compreendida como um fato contingente, produto momentâneo da evolução social; e o direito do proprietário, como justificado e ao mesmo tempo limitado pela missão social que lhe incumbe em consequiência da situação particular em que se encontra. ${ }^{15}$

Os pensamentos sociais acima citados acabaram por influenciar a legislação moderna de inúmeros países, dentre estes o próprio Brasil que, desde 1946 traz no corpo de suas constituições o aspecto funcional; porém, a partir de 1988, com a promulgação da constituição cidadã, assim denominada por

10 LOPES, Ana Frazão de Azevedo Lopes. Empresa e propriedade: Função social e abuso de poder econômico. São Paulo: Quartier Latin, 2006, p. 91.

11 COMTE, Auguste. Coleção Grandes Cientistas Sociais. São Paulo: Ática, 1989.

12 Op. Cit.

13 DUGUIT, Leon. Fundamentos de direito. Campinas: LZN, 2003.

14 TEPEDINO, Gustavo; SCHREIBER, Anderson. Questôes agrárias: julgados comentados e pareceres. São Paulo: Método, 2002.

15 Op. cit. 22 p. 
Ulisses Guimarães passou a disciplinar o princípio da função social como direito e garantia fundamental.

Com o advento da Carta Magna de 1988, ganha relevo a questão da função social na cena jurídica. As discussóes doutrinárias passam a focar o tema a partir de sua base constitucional. De fato a Constituição Federal, ao adotar o princípio da função social, retomou a discussão da finalidade social do próprio direito. ${ }^{16}$

A partir de 1988, o ordenamento pátrio positivou a função social, em inúmeros artigos constitucionais que disciplinavam o direito de propriedade e seu dever para com a função social, os quais, mais tarde, por força hierárquica, influenciaram inúmeras leis infraconstitucionais.

\section{A função social da propriedade rural na constituição federal brasileira}

Em 1919, com a promulgação da Constituição de Weimar, a função social da propriedade apareceu inserida dentro de um texto normativo, precisamente no Art. 153. Referido texto, criado sob influência dos pensadores acima descritos, acabou por influenciar os ordenamentos jurídicos de vários países, sendo certo que, em 1946, a Constituição Federal trazia em seu corpo o Art. 147 que se assemelhava muito, segundo Tepedino e Schreiber ${ }^{17}$, ao texto de Weimar.

O texto em questão acabou por ser repetido pela Constituição de 1967 que elevou a função social à categoria de princípio da ordem econômica e social.

No ordenamento jurídico brasileiro, desde a Constituição democrática de 1946, a propriedade perdeu o caráter de direito absoluto de uso, gozo e disposição de seu titular. A partir de então, a função social passou a figurar como elemento constitutivo do conceito jurídico de propriedade. ${ }^{18}$

Já a festejada Constituição de 1988, que inaugurou no país o Estado Democrático de Direito, trouxe, dentro de seu texto final, a positivação do

\footnotetext{
16 FERREIRA, Jussara Suzi Assis Borges Nasser. Op. cit., p. 36, 17 TEPEDINO, Gustavo; SCHREIBER, Anderson. Op. cit., p. 118. 18 GOULART, Marcelo Pedroso. Ministério público nos processos que envolvam litígios coletivos pela posse da terra rural. BARROSO, Lucas Abreu; PASSOS, Cristiane Lisita (coords.) Questões Agrárias: julgados comentados e pareceres. São Paulo: Método, 2002.
} 
princípio da função social da propriedade rural que está inserida como garantia fundamental e como princípio da ordem econômica, nos seguintes termos:

Art. $5^{\circ}$ - Todos são iguais perante a lei, sem distinção de qualquer natureza, garantindo-se aos brasileiros e aos estrangeiros residentes no País a inviolabilidade do direito à vida, à liberdade, à igualdade, à segurança e à propriedade, nos termos seguintes:

$[\ldots]$

XXIII - a propriedade atenderá a sua função social Art. 170 - A ordem econômica, fundada na valorização do trabalho humano e na livre iniciativa, tem por fim assegurar a todos existência digna, conforme os ditames da justiça social, observados os seguintes princípios:

[...]

III - função social da propriedade.

Desta forma, constitui princípio ordenador da propriedade privada e fundamento da atribuição deste direito, incidindo sobre seu próprio conteúdo.

Ocorre que a Constituição dispõe, ainda, sobre a função social da propriedade no capítulo específico inerente à política agrária, afirmando que:

Art. 186 - A função social é cumprida quando a propriedade rural atende, simultaneamente, segundo critérios e graus de exigência estabelecidos em lei, aos seguintes requisitos:

I - aproveitamento racional e adequado;

II - utilização adequada dos recursos naturais disponíveis e preservação do meio ambiente;

III - observância das disposições que regulam as relações de trabalho;

IV - exploração que favoreça o bem-estar dos proprietários e dos trabalhadores.

Para alguns autores o tema e o princípio da função social estão dispostos no ordenamento pátrio há tempos, muito antes da promulgação da Constituição de 1988. Ocorre, porém, como muito bem coloca Cristiane Lisita Passos ${ }^{19}$, não se tratava da função social como hoje é entendida e conceituada nos termos do artigo 186 e seus incisos, mas tão somente de lei com caráter puramente econômico com vistas à produtividade.

A função social no direito brasileiro vem de longa data, da época das Sesmarias, quando as leis de Portugal, Ordenaçoees Filipinas e Manoelinas, resguardavam o uso do solo com vistas à sua melhor produtividade.

19 PASSOS, Cristiane Lisita. A função social do imóvel rural. PASSOS, Cristiane Lisita; BARROSO, Lucas Abreu. (coord.)Direito Agrário Contemporâneo. Belo Horizonte: Del Rey, 2004. 
Entretanto, é necessário frisar que havia preocupação somente com a produtividade, não se observando outros elementos como a preservação dos recursos naturais, conforme parâmetros atuais. ${ }^{20}$

Quanto à questão puramente econômica, cabe aqui tecer comentário de que atrasados doutrinadores ainda insistem, demonstrando uma visão míope, que a função social é cumprida quando a propriedade rural atinge índices de produtividade, jogando no lixo os deveres constitucionalmente impostos à propriedade rural quanto ao bem-estar coletivo, dos trabalhadores e do meio ambiente.

\section{Conceito de função social da propriedade rural}

Uma vez localizado em nosso ordenamento constitucional o princípio da função social da propriedade rural, neste ponto se faz necessária uma precisa conceituação deste princípio para que se possa visualizá-lo, caracterizá-lo e dimensioná-lo, inclusive quanto às suas repercussões.

$\mathrm{O}$ direito de propriedade, aliás, encontra-se assegurado ao indivíduo em quase que a totalidade das leis do mundo e, na maioria dos casos, condicionado a função social que lhe é inerente.

Nesse diapasão, a Constituição de 1988 garante em seu Art. 5, inciso XXIII, o direito de propriedade; porém, o faz de forma relativa e condicional ao cumprimento da função social da propriedade, Art. 184.

[...] da mesma forma que é conferido um direito subjetivo para o proprietário reclamar a garantia da relação de propriedade, é atribuído ao Estado e à coletividade o direito subjetivo público para exigir do sujeito proprietário a realização de determinadas ações, a fim de que a relação de propriedade mantenha sua validade no mundo jurídico. ${ }^{21}$

Apesar de alguns autores entenderem que o termo função social da propriedade é vago e indeterminado, o que reflete o pensamento míope e minoritário, senão quase que extinto, inúmeros pensadores vêm definindo o instituto de forma clara e precisa.

Antônio C. Vivanco, citado por Grace Virginia Ribeiro de Magalhães Tanajura, assim define o instituto da função social da propriedade:

20 Op. cit., p. 44.

21 DERANI, Cristiane. A propriedade na constituição de 1988 e o conteúdo da função social. Revista de Direito Ambiental. São Paulo: Revista dos Tribunais, v.27, p. 59, 2002. 
La función social es mi más ni menos que el reconocimento de todo titular del dominio, de que por ser um miembro de la comunidad tiene derechos y obligaciones com relación a los demás miembros de ella, de manera que si él há podido llegar a ser titular del dominio, tiene lá obligación de cumplir com el derecho de los demás sujetos, que consiste em no realizar acto alguno que pueda impedir u obstaculizar el bien de dichos sujetos, $o$ sea, de lá comunidad. El direto a la cosa se manifesta concretamente em el poder de usaria y usufructaria. El deber que importa o comporta la obligación que se tiene com los demás sujetos se traduce em la necessidad de cuidarla a fin de que no pierda su capacidad productiva y produzca frutos em beneficio del titular e indirectamente para satisfaccion de lãs necessidades de los demás sujetos de la comunidad. ${ }^{22}$

Já Antônio José de Mattos Neto ensina que: “a função social é paradigma que congrega duas atribuiçôes: a social propriamente dita e a econômica. Ambos os aspectos - o social e o econômico - fazem parte do conceito função social da propriedade" ${ }^{23}$

Nota-se que ambos os doutrinadores acima são enfáticos ao trazerem para dentro do princípio da função social, a obrigação social e, não somente a obrigação econômica. Ou seja, visa o bem-estar coletivo no sentido mais amplo que se possa dar a palavra, relegando ao segundo plano o interesse individual.

No entendimento de Luciano de Souza Godoy:

A propriedade agrária, como corpo, tem na função social sua alma. Se a lei reconhece o direito de propriedade como legítimo, e assim deve ser, como é da tradição de nosso sistema, também condiciona ao atendimento de sua função social. Visa não só o interesse individual do titular, mas também ao interesse coletivo, que suporta e tutela o direito de propriedade. A propriedade agrária como bem de produção, destinada à atividade agrária, cumpre função social quando produz de forma adequada, respeita as relações de trabalho e também observa os ditames de preservação e conservação do meio ambiente. $^{24}$

22 TANAJURA, Grace Virgínia Ribeiro de Magalhães. Função social da propriedade rural: com destaque para a terra no Brasil contemporâneo. São Paulo: LTr, 2000, p. 24.

23 MATTOS NETO, Antonio de. Função ética da propriedade imobiliária no novo código civil. In: BARROS, Lucas de Abreu Barros ; PASSOS, Cristiane Lisita (Coords). Direito Agrário Contemporâneo. Belo Horizonte: Del Rey, 2004, p. 78.

24 GODOY, Luciano de Souza. Direito Agrário Constitucional: o regime de propriedade. São Paulo: Atlas, 1998 
Destacam-se, assim, fazendo coro as palavras de Cristiane Lisita Passos ${ }^{25}$, três princípios a serem cumpridos pelo proprietário rural no que tange à função social do imóvel rural: o ecológico, o social e o econômico.

Segundo Tepedino e Schreiber ${ }^{26}$, a doutrina italiana soube conceituar a função social não como categoria oposta ao direito subjetivo, mas como um elemento capaz de alterar-lhe a estrutura, atuando como critério de valoração do exercício do direito.

Diante da conceituação acima transcrita, resta evidente, que há cumprimento da função social da propriedade rural, de forma ampla e genérica, quando se cumpre a legislação fundiária, agrária, ambiental, trabalhista, tributária e civil.

Ou seja, função social da propriedade rural nada mais é do que a função/ obrigação constitucional que a propriedade rural tem de, na forma da legislação em vigor, promover o crescimento econômico e social de todos aqueles que dela dependam, respeitando-se o meio ambiente e as relações de trabalho.

\section{Função social da propriedade rural e o conflito de requisitos expressos nas normas superiores}

Muito se debate hodiernamente quanto ao descumprimento da função social e seus respectivos efeitos. Acalorada discussão existe quanto à aplicação do artigo 184 da Constituição Federal no caso da propriedade ruralque não pode descumprir alguns ou um único dos requisitos da função social e, deve ao mesmo tempo, ser produtiva.

O artigo 184 da Constituição Federal, precisamente determina que: "Art. 184. Compete à União desapropriar por interesse social, para fins da reforma agrária, o imóvel rural que não esteja cumprindo sua função social [...]”.

É claro que, segundo o Art. 184 da Constituição Federal, que, uma vez não cumprida a função social, o imóvel descumpridor fica suscetível de ser desapropriado por interesse social para fins da reforma agrária, nos termos da legislação infraconstitucional, como a lei n. 8.629 de 25 de fevereiro de 1993 e a lei complementar n. 76 de 06 de julho de 1993.

Entretanto, no mesmo plano superior das normas, precisamente, o Art.185, em seu inciso II, veda a desapropriação de imóvel rural apenas produtivo: "Art. 185 - São insuscetíveis de desapropriação para fins de reforma agrária: [...] II - a propriedade produtiva [...]." 
No mesmo plano hierárquico, com mesma data e mesma especificidade, há duas normas constitucionais conflitantes, sendo que uma determina a desapropriação por interesse social, para fins da reforma agrária, do imóvel rural que não cumpra, de forma simultânea, os requisitos da função social definida no Art. 186 da Constituição Federal; a outra norma veda a aludida desapropriação pelo simples critério da existência ou não do cumprimento de índices economicistas (produtividade). Sem dúvida alguma, tal fato caracteriza-se como sendo uma antinomia jurídica.

Tércio Sampaio Ferraz Jr. citado por Maria Helena Diniz traz em seus ensinamentos, de forma precisa, o conceito de antinomia real:

A oposição que ocorre entre duas normas contraditórias (total ou parcialmente), emanadas de autoridades competentes num mesmo âmbito normativo que colocam o sujeito numa posição insustentável pela ausência ou inconsistência de critérios aptos a permitir-lhe uma saída nos quadros de um ordenamento dado. ${ }^{27}$

Utilizando as felizes palavras de Joaquim Modesto Pinto Junior e Valdez Adriani Farias ${ }^{28}$, não resta dúvida que a celeuma posta se resolve mediante a interpretação sistemática, não se esquecendo que o ordenamento jurídico deve ser considerado como um todo informado por princípios explícitos e implícitos, e que a integração isolada de uma norma pode deturpar seu verdadeiro significado, até mesmo podendo resultar num sentido que possa ir contra os fins da ordem jurídica.

Não se pode esquecer que a Constituição Federal seguiu os princípios da função social como um todo, conforme bem explanado no item 1 (um) deste trabalho, acompanhando a própria evolução do direito e social.

Por meio de uma análise sistemática da Constituição Federal (Art. 5. XXIII, Art. 7, Art. 170 III, Art. 184, e o Art. 186), verifica-se que o espírito do texto albergou a evolução do direito através dos tempos, contemplando os fatores sociais aclamados por Comte e Duguit; aliás, trata-se de Constituição instituidora do Estado Democrático de Direito que possui como um de seus fundamentos a dignidade da pessoa humana (Art. 1. III).

Desta feita, aceitar como válida e norma impeditiva da desapropriação o Art. 184 II da Constituição Federal e considerar como único requisito válido da função social a questão econômica, relegando para o ostracismo os demais

27 DINIZ, Maria Helena. Conflito de normas. São Paulo: Saraiva, 2005. 19 p. 28 PINTO JUNIOR, Joaquim Modesto; FARIAS, Valdez Adriani. Função social da propriedade: dimensões ambiental e trabalhista. Brasília: Núcleo de estudos agrários e desenvolvimento rural, 2005, p. 17. 
requisitos intrínsecos do Art. 186 da Constituição Federal que contemplam os valores sociais do trabalho (Art. 1. IV e 7.) e os valores ambientais (Art. 225) entre outros inúmeros que são protegidos pela Lei Maior, é rasgar a própria constituição federal e negar a existência do Estado democrático de direito.

Como se vê, a Constituição dá conteúdo positivo à função social, condicionando a legitimidade do domínio ao atendimento, pelo titular, de valores sociais e existenciais não proprietários, notadamente no que concerne às relaçôes de trabalho e ao meio ambiente. ${ }^{29}$

Analisando o confronto em questão, Marcelo Dias Varella alerta que:

[...] Logo, ao se considerar como princípio a suficiência apenas do primeiro requisito para o cumprimento da função social como excludentes dos demais, conclui-se que os outros três incisos (Art. 186 II, III e IV) não teriam qualquer utilidade, embora presentes no texto constitucional, não poderiam servir de critério para averiguação do cumprimento da função social da propriedade e por conseqüência da realização de desapropriação com fins de reforma agrária. ${ }^{30}$

Nota-se, inclusive, que o texto constitucional que fixa a forma de cumprimento da função social (Art. 186), descrevendo todos os requisitos que devem ser atingidos, possui em sua redação o advérbio de modo simultaneamente, que acaba por exigir o cumprimento conjunto de todos os requisitos da função social sob pena de atrair a desapropriação estabelecida no Art. 184 da Norma Maior.

Pensar de forma contrária, ou seja, de que o Art. 185, II possui prevalência sobre os demais artigos, é o mesmo que anular todo o Art. 186 e o caput do Art. 184. É conceituar o cumprimento da função social diversamente como feito logo acima, descrevendo-a de forma simplória como índice de produtividade pré-definido por lei.

Com efeito, verificado o que seria a antinomia, partir-se-ia para a aplicação dos critérios antes aventados para solucioná-la. Assim, em se optando pela prevalência do art. 185, inciso II, o uso dessa técnica faria com que fossem anulados todo o art. 186 e o caput do

29 TEPEDINO, Gustavo; SCHREIBER, Anderson. O papel do poder judiciário na efetivação da função social da propriedade. In: STROZAKE Juvelino (org.) Questôes agrárias: julgados comentados e pareceres. São Paulo: Método, 2002, p.125.

30 VARELLA, Marcelo Dias. Introdução ao direito à reforma agrária: o direito face aos novos conflitos sociais. São Paulo: LED, 1998. 
art. 184 da Constituição Federal, conforme os critérios para solução de antinomias reais propostos por Bobbio. ${ }^{31}$

Não se pode confundir função social com aproveitamento econômico, haja visto que o aproveitamento econômico é apenas um dos requisitos da função social materializado pela produtividade (Art. 186 I), devendo este requisito ser associado, segundo Tepedino e Schreiber ${ }^{32}$, à promoção de valores consagrados pela Constituição nos princípios e objetivos fundamentais da República.

Ao se solucionar o conflito posto, verifica-se que são requisitos da função social aqueles descritos nos incisos do Art. 186 da Constituição Federal que, se não cumpridos de forma simultânea, nos termos da legislação infraconstitucional, darão azo à possibilidade de desapropriação por interesse social para fins da reforma agrária, não valendo um único requisito como meio impeditivo da desapropriação descrita no Art. 184.

\section{A discussão prática da função social da propriedade rural}

O campo prático de discussão quanto ao tema função social é a disputa por terra existente em nosso país. De um lado, os movimentos sociais, nem sempre com interesses legítimos, clamam pelo direito constitucional e social que os excluídos do campo têm à terra. De outro, os proprietários rurais, lastreados no arcaico direito inviolável de propriedade resistem e protegem seu território.

No meio desta verdadeira guerra encontram-se o INCRA (Instituto Nacional de Colonização e Reforma Agrária) e o Poder Judiciário que, por meio de suas atribuições, tentam solucionar as contendas devolvendo à sociedade a paz no campo.

Porém, todos os envolvidos na questão, até os dias de hoje ainda debatem, discutem e resolvem as questóes acerca da propriedade rural, sua função social e conseqüente desapropriação para fins da reforma agrária, de forma míope, apequenando e encobrindo o verdadeiro debate sobre o assunto que, como visto acima, é bem mais amplo.

Diz-se isso uma vez que todos os setores envolvidos na questão insistem, apesar da Constituição Federal e seu Art. 186 existirem há mais de 18 (dezoito) anos, em minimizar a discussão quanto à função social da propriedade e ao direito ou não à desapropriação, quando do cumprimento ou não dos índices de produtividade.

31 PINTO JUNIOR, Joaquim Modesto; FARIAS, Valdez Adriani. Função social da propriedade: dimensões ambiental e trabalhista. Brasília: Núcleo de estudos agrários e desenvolvimento rural, 2005, p. 18.

32 Op. cit., p. 126. 
Ou seja, ao invés de haver um debate mais amplo sobre o tema, abrangendo todos os requisitos de cumprimento da função social dispostos, como já visto, nos incisos do Art. 186 da Constituição Federal, todas as partes continuam discutindo o direito insculpido no Art. 184 da Constituição Federal pelo viés exclusivo da produtividade, relegando os demais requisitos.

Note-se que os próprios interessados na reforma agrária, ao invés de trazer à discussão todos os aspectos da função social, conforme acima expostos, continuam a cometer o erro histórico de apenas e tão somente discutir os requisitos econômicos da produtividade da propriedade rural passível de desapropriação.

Tal fato é de fácil visualização por meio de simples leitura da entrevista concedida por um dos lideres do MSLT (Movimento de Libertação dos Sem Terra) ao jornal Folha de S. Paulo:

Integrantes do MLST (Movimento de Libertação dos Sem Terra) invadiram entre a noite de segunda-feira e a madrugada de anteontem uma fazenda na região de Prata (653 km de Belo Horizonte). De acordo com Ismael Costa, da coordenação nacional do movimento, aproximadamente 450 pessoas entraram na fazenda Barreiro. "A área é improdutiva. Tem cerca de 800 alqueires e só há umas 30 vacas", disse ele. Costa relatou que, desde o início do ano, o MLST ocupou 12 fazendas no Estado. A Polícia Militar informou que o clima era tranqüilo na fazenda na tarde de ontem. A reportagem não conseguiu localizar o proprietário da fazenda. ${ }^{33}$

Aliás, o mais famoso líder do MST, João Pedro Stédile, em entrevista à rádio Mundo Real, disse:

Toda a área econômica ficou neoliberal. Nesse cenário, quase todos os movimentos sociais tiveram pontos positivos e negativos. No campo específico da Reforma Agrária, o nosso balanço é negativo porque as medidas que o governo tomou ao longo de quatro anos beneficiaram muito mais o agronegócio do que a Reforma Agrária de maneira que nós não conseguimos avançar em nada. O governo não teve coragem sequer de atualizar os indices de produtividade que medem se uma fazenda pode ou não ser desapropriada. Os índices usados atualmente são do censo do Incra (Instituto Nacional de Colonização e Reforma Agrária) de 1975. No conjunto da política agrícola do governo continuou-se privilegiando a agricultura para exportação. A agricultura brasileira deve em primeiro lugar cumprir a sua função primordial que é produzir alimentos saudáveis e baratos para o povo

33 Folha de S. Paulo. Banco de Notícias. Disponível em: <http://www1.folha.uol.com.br/folha/ brasil/ult96u89680.shtml>. Acessado em: 22 fev. 2007. 
brasileiro que, infelizmente, continua faminto ou se alimentando aquém das necessidades básicas nutricionais. ${ }^{34}$ (grifo nosso)

Da mesma forma, mas com toda razão, pois defendem seus interesses, os produtores rurais também possuem o arcaico e errôneo hábito de discutir exclusivamente o aspecto econômico da função social, ou seja, os índices de produtividade.

Um grupo de 150 integrantes do Movimento dos Sem-Terra (MST) invadiu na manhã de ontem a Fazenda Santa Maria, em Santa Maria do Oeste, a 350 quilômetros de Curitiba. De acordo com a Polícia Militar, não houve confronto. Os invasores são excedentes de assentamentos da região. A proprietária, Neide Alves Torres, entraria ontem na Justiça com um pedido de reintegração de posse. Ainda segundo a PM, 30\% dos 190 alqueires são área de preservação e o restante é usado para agricultura e pecuária, mas a fazenda estaria penhorada, por causa de dívidas. ${ }^{35}$

Como se não bastasse o erro crasso cometido pelas duas principais partes interessadas no tema, o órgão federal competente para promover a reforma agrária no país também comete o mesmo pecadilho, o que acaba por prejudicar a própria reforma agrária, haja visto que este órgão apenas considera passível de desapropriação para fins da reforma agrária a propriedade rural improdutiva.

Cerca de 60 famílias invadiram, neste fim de semana, a fazenda Garrote, no município de Brejo da Madre de Deus $(214 \mathrm{~km}$ de Recife), região agreste do Estado.

$[\ldots]$

O movimento reivindica a propriedade - de 1.800 hectares - para a reforma agrária, sob a alegação de que ela é improdutiva.

O Incra (Instituto Nacional de Colonização e Reforma Agrária), no entanto, diz ter feito uma vistoria no mês passado na qual declarou-a produtiva. A Justiça chegou, inclusive, a conceder a reintegração de posse ao proprietário, que não foi localizado ontem pela reportagem.

$[\ldots] .^{36}$

34 Rádio Mundo Real. Banco de Entrevistas. Disponível em: <http://www.radiomundoreal. $\mathrm{fm} / \mathrm{rmr} /$ ?q=pt/node/10476>. Acesso em:22 fev. 2007.

35 União Democrática Ruralista. Banco de Notícias. Disponível em <http:// http://www.udr.org. br/invasao5.htm>. Acesso em 22 fev. 2007.

36 Folha de S. Paulo. Banco de Notícias. Disponível em: <http:// http://www1.folha.uol.com. br/folha/brasil/ult96u68585.shtml>. Acesso em: 22 fev. 2007. 
Por fim, compete tecer considerações quanto à visão dos Tribunais Superiores sobre o tema da função social (Art. $186 \mathrm{CF}$ ) e a desapropriação de terras para fins da reforma agrária (Art. 184).

Muito embora tenha sido realizada pesquisa intensa na página eletrônica do STF, infelizmente não foi localizada a manifestação do STF sobre os demais requisitos da função social da propriedade rural, cingindo-se o tema exclusivamente na seara míope dos índices de produtividade.

Necessário lembrar que, se o judiciário, ainda não se manifestou por meio de seu órgão máximo acerca do assunto, deve-se pelo fato de não ter sido provocado pelas partes interessadas, ante a sua natureza inerte.

Porém, como bem lembraram Pinto Junior e Farias ${ }^{37}$, houve de forma tímida, por parte do STF, a seguinte decisão proferida na ADI n. 2213 de relatoria do Ministro Celso de Mello:

ADI 2.213/DF - Relator(a): Min. CELSO DE MELLO - Publicação: DJ DATA-23-04-04 (...) RELEVÂNCIA DA QUESTÃO FUNDIÁRIA - O CARÁTER RELATIVO DO DIREITO DE PROPRIEDADE - A FUNÇÃO SOCIAL DA PROPRIEDADE - A IMPORTÂNCIA DO PROCESSO DE REFORMA AGRÁRIA - (...) - A PRIMAZIA DAS LEIS E DA CONSTITUIÇÃO DA REPUBLICA NO ESTADO DEMOCRÁTICO DE DIREITO - $\mathrm{O}$ direito de propriedade não se reveste de caráter absoluto, eis que, sobre ele, pesa grave hipoteca social, a significar que, descumprida a função social que lhe é inerente (CF 5. XXIII), legitimarse-á a intervenção estatal na esfera dominial privada, observados, contudo, para esse efeito, os limites, as formas e os procedimentos fixados pela própria constituição da República. $O$ acesso à terra, a solução dos conflitos sociais, o aproveitamento racional e adequado do imóvel rural, a utilização apropriada dos recursos naturais disponiveis e a preservação do meio ambiente constituem elementos de realização da função social da propriedade. [...] pois só se tem por atendida a função social que condiciona o exercício do direito de propriedade, quando o titular do dominio cumprir a obrigação (1) de favorecer o bem-estar dos que na terra labutam; (2) de manter niveis satisfatórios de produtividade; (3) de assegurar a conservação dos recursos naturais; $e$ (4) de observar as disposiçôes legais que regulam as justas relações de trabalho entre os que possuem o dominio e aqueles que cultivam a propriedade [...]. (grifo nosso).

37 PINTO JUNIOR, Joaquim Modesto; FARIAS, Valdez Adriani. Op. cit., p. 46. 
Resta evidente que a discussão equivocada em torno exclusivamente da produtividade da terra, por todas as partes envolvidas no problema, acaba por provocar distorçôes sem precedentes prejudicando, principalmente, a própria reforma agrária.

Tanto o é assim que, ao invés de exigirem o cumprimento do Art. 186 da Constituição Federal, levantando assim inúmeras propriedades rurais que não cumprem os demais requisitos da função social dos setores interessados, preferem reivindicar à atualização dos índices de produtividade, o que seria desnecessário se o INCRA cumprisse o Art. 186 da CF.

A Confederação Nacional dos Trabalhadores na Agricultura (Contag) avalia que a possibilidade de avançar mais a reforma agrária no Brasil não é culpa ou má vontade do governo Lula. Segundo o diretor de Políticas Agrárias e Meio Ambiente da Contag, Paulo Caralo, o poder Judiciário e a desatualização dos índices de produtividade são entraves. "Percebemos que não é má vontade do presidente Lula, foram feitas centenas de desapropriações, mas o latifúndio entra na Justiça e infelizmente o Judiciário dá reintegração de posse para o fazendeiro. Foram várias terras desapropriadas pelo governo federal e o Incra perdeu para o proprietário depois do termo de reintegração de posse", explicou. Caralo ainda enfatiza a ausência da atualização dos indices de produtividade também é um problema. Os atuais números foram estabelecidos em 1980, a partir de dados estatísticos de 1975. Com a atualização dos indices, a expectativa destacada pelos movimentos sociais é a de que propriedades rurais consideradas atualmente produtivas se revelem aptas a ser desapropriadas para a reforma agrária em regiôes de alto nivel de conflito fundiário, como o Sul e o Nordeste. ${ }^{38}$ (grifo nosso)

Se a Contag se ativesse ao Art. 186 da Constituição Federal conforme aqui exposto e, através de seus meios, pressionasse o INCRA para que este órgão cumprisse com os ditames constitucionais, não haveria qualquer necessidade de debates políticos desgastantes quanto à atualização dos índices de produtividade.

Ou seja, cumprindo-se a lei (artigo 186 da CF), haverá terras suficientes em nosso país para desapropriação para fins da reforma agrária, restando aos proprietários de aludidas terras o direito e o dever de cumprir, de forma integral e simultânea, com a função social da propriedade rural.

38 Agência de Notícias Brasil. Banco de Notícias. Disponível em: <http://www.agenciabrasil. gov.br/noticias/2007/01/30/materia.2007-01-30.3570568294/view>. Acesso em: 22 fev. 2007. 


\section{Considerações finais}

A função social da propriedade rural é uma garantia para toda a sociedade, garantia essa adquirida com a evolução do pensamento social, conforme acima visto. Passados anos de sua idealização, acabou por assumir status de garantia constitucional em nosso país. Porém, talvez por razões de conveniência, nunca foi posta em prática nos termos como definida.

Passados mais de 18 (dezoito) anos da promulgação da Constituição Federal de 1988, não há efeitos práticos da total utilização e aplicação integral do texto constitucional existente no artigo 186. Até hoje, a sociedade insiste em discutir, com o pensamento focado no século passado, índices de produtividade da terra, deixando de lado aspectos mais relevantes como o respeito ao meio ambiente, as relações do trabalho a dignidade da pessoa humana, entre outros.

Como visto pelas partes envolvidas, se uma porção de terra é produtiva esta é inviolável, mesmo que empregue em sua produtividade mão-de-obra em condiçōes análogas à escravidão. Aqui, se realmente isso acontecer, no máximo haverá aplicação de multas trabalhistas, indenizaçōes por danos morais coletivo e abertura de inquérito policial.

O pior é que, em um país que se acostumou a fabricar leis que não são aplicadas, estuda-se a possibilidade de editar lei para que, em caso de trabalhos em condições análogas à escravidão, haja a expropriação da terra. Esquecem os envolvidos que já há lei, inclusive constitucional, permitindo a desapropriação da terra em caso de trabalho escravo, haja vista que o fato em si (utilização de mãode-obra em condições análogas aàescravidão) ofende o inciso III do Art.186. Ou seja, não há necessidade de lei, mas sim de aplicação das leis já existentes.

Pelo exemplo posto, se verifica que há necessidade imperiosa de revisão quanto à discussão prática acerca da função social da propriedade rural e seus efeitos, trazendo à baila os aspectos trabalhistas, ambientais, tributários e sociais propriamente ditos que norteiam a função social.

No momento, não há razão de serem discutidas, na esfera política, possíveis alteraçōes dos índices de produtividades: deve-se, sim, discutir formas de se cumprir o disposto no artigo 186 da Constituição Federal em sua inteireza, o que certamente trará benefícios para toda a sociedade brasileira.

Se todas as partes cumprirem com o ordenamento Constitucional, no que tange a propriedade rural, haverá maior respeito à legislação trabalhista, tributária, ambiental e a dignidade da pessoa humana, o que de certo beneficiará a todos.

E, caso não haja respeito, por parte dos proprietários rurais, do Art. 186 da Constituição Federal, mais terras restarão passiveis de desapropriação para fins da reforma agrária, o que também beneficiará toda uma coletividade, inclusive contribuindo para amenizar a desigualdade social no campo. 


\section{Referências}

COMTE, Auguste. Coleção grandes cientistas sociais. José Albertino Rodrigues (Org.). São Paulo: Ática, 1989.

DERANI, Cristiane. A propriedade na constituição de 1988 e o conteúdo da função social. Revista de Direito Ambiental, São Paulo, Revista do Tribunais, v. 27, 2002.

DINIZ, Maria Helena. Conflito de normas. São Paulo: Saraiva, 2005.

DUGUIT, Leon. Fundamentos de direito. Trad.Ricardo Rodrigues Gama. Campinas: LZN, 2003.

FERREIRA, Jussara Suzi Assis Borges Nasser. Função Social e Função Ética da Empresa. ARGUMENTUM Revista de Direito. Universidade de Marília. v. 04, 2004.

GODOY, Luciano de Souza. Direito agrário constitucional: o regime de propriedade. São Paulo: Atlas, 1998

GOULART, Marcelo Pedroso. Ministério público nos processos que envolvam litígios coletivos pela posse da terra rural. In: STROZAKE, Juvelino José (org.) Questôes agrárias: julgados comentados e pareceres. São Paulo: Método, 2002.

HOBBES, Thomas. Leviatã. Trad. Alex Marins. São Paulo: Martin Claret, 2002.

HOBBES, Thomas. Os grandes filósofos do direito.Clarence Morris (org.). Trad. Reinaldo Guarany. São Paulo: Martins Fontes, 2002.

LOPES, Ana Frazão de Azevedo. Empresa e propriedade: função social e abuso de poder econômico. São Paulo: Quartier Latin, 2006.

MARX, Karl. ENGELS, Friedrich. Manifesto do Partido Comunista. Trad.Pietro Nassetti. São Paulo: Martin Claret, 2002.

MARX, Karl. Manuscritos Econômicos Filosóficos. Trad. Alex Marins. São Paulo: Martin Claret, 2002.

MATTOS NETO, Antonio de. Função ética da propriedade imobiliária no novo código civil. BARROS, Lucas de Abreu; PASSOS, Cristiane Lisita (ccords.). Direito agrário contemporâneo. Belo Horizonte: Del Rey, 2004.

PASSOS, Cristiane Lisita. A função social do imóvel rural. BARROS, Lucas de Abreu; PASSOS, Cristiane Lisita (ccords.). Direito agrário contemporâneo. Belo Horizonte: Del Rey, 2004.

PINTO JUNIOR, Joaquim Modesto; FARIAS, Valdez Adriani. Função social da propriedade: dimensões ambiental e trabalhista. Brasília: Núcleo de Estudos Agrários e Desenvolvimento Rural, 2005.

ROUSSEAU, Jean-Jacques. Do contrato social. Trad. Pietro Nassetti. São Paulo: Martin Claret, 2003.

TANAJURA, Grace Virgínia Ribeiro de Magalhães. Função social da propriedade rural: com destaque para a terra no Brasil contemporâneo. São Paulo: LTr, 2000.

TEPEDINO, Gustavo; SCHREIBER, Anderson. O papel do poder judiciário na efetivação da função social da propriedade.BARROS, Lucas de Abreu; PASSOS, Cristiane Lisita (ccords.). Direito agrário contemporâneo. Belo Horizonte: Del Rey, 2004. 
A função social da propriedade rural

VARELLA, Marcelo Dias. Introdução ao direito à reforma agrária: o direito face aos novos conflitos sociais. São Paulo: LED, 1998. 
